\title{
Migration in the Enlarged European Union: Empirical Evidence for Labour Mobility in the Baltic States
}

\author{
d'Artis Kancs and Julda Kielyte
}

ISSN: 2031-4892

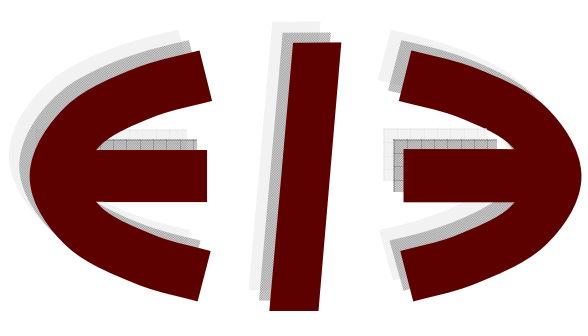

\section{EERI}

Economics and Econometrics Research Institute Avenue de Beaulieu 1160 Brussels

Belgium

Tel: +3222993523

Fax: +322 2993523

www.eeri.eu 


\title{
Migration in the Enlarged European Union: A Perspective from the Baltic States*
}

\author{
d’Artis Kancs ${ }^{\dagger} \quad$ Julda Kielyte ${ }^{\ddagger}$
}

\begin{abstract}
The free movement of workers is a highly controversial issue with regard to the Eastern enlargement of the European Union (EU). Members of the EU are extremely anxious of mass immigration flows from Central and Eastern Europe countries (CEECs). This paper estimates the potential migration and analyses socio-economic impacts of migration in the context of the EU enlargement. How many people might migrate from the Eastern European transition countries to Western Europe, and what will be the socio-economic consequences for home and host countries? In order to answer these questions we draw on previous literature as well as on our empirical work. In the empirical analysis we evaluate the size and the structure of current and future migration to Western Europe. In particular, we estimate the future migration pressure, based on economic conditions in the Baltic States and Western Europe. Our empirical results suggest that depending on assumptions 3-5 percent of home countries working population might emigrate after opening labour markets in the old EU member states.
\end{abstract}

Keywords: International labour migration, EU integration, panel data, econometric model.

JEL classification: F12, F22, L11.

*The authors acknowledge helpful comments from Thomas Straubhaar and Tim Hatton, the UN WIDER and AABS conference participants in Helsinki and Baltimore, and seminar participants in HWWI and University of Kiel. The authors acknowledge financial support from the Research Grant 'International Labor Migration in a Globalizing Economy'. The authors are solely responsible for the content of the paper. The views expressed are purely those of the author and may not in any circumstances be regarded as stating an official position of the European Parliament.

${ }^{\dagger}$ Massachusetts Institute of Technology (MIT), University of Kiel (IFR), International Institute for Applied Systems Analysis (IIASA), and Economics and Econometrics Research Institute (EERI). Corresponding address: Massachusetts Institute of Technology, 77 Massachusetts Avenue, Cambridge, MA 02139-4307, USA. E-mail: kancs@mit.edu.

${ }_{\ddagger}^{\ddagger}$ European Parliament (DG Research), World Trade Organization (WTO), University of Hamburg (HWWA), and Economics and Econometrics Research Institute (EERI). Corresponding address: European Parliament, DG Research, Division for Economic, Monetary and Budgetary Affairs. E-mail: Julda.Kielyte@wto.org. 


\section{Introduction}

In 2004 the first ten Central and Eastern European countries (CEECs) will become new EU Member States. In light of the EU Eastern enlargement a controversial issue has been the question of whether citizens of the new EU Member States should immediately gain access to the Western European labour markets in EU. According to the current EU legislation, the free movement of EU workers within the Single European market is an integral part of the Treaty of the European Community. It belongs to the acquis communautaire that has to be adopted by the new EU Member States before joining the EU. Moreover, it has to be granted reciprocally to citizens from old and new EU Member States. In spite of these treaty provisions, labour migration issues have been on the EU enlargement agenda of the EU Eastern enlargement negotiations for a long time. Due to intensive political pressure from the old EU member states most of the current EU Member States have accepted a transition period to free labour movement. ${ }^{1}$

Up to now, labour migration flows from the CEE accession and candidate countries are heavily restricted by EU legislation. The Europe Agreements do not impair the authority of individual EU member states to regulate the immigration of labour and persons from the CEECs. The removal of institutional barriers to labour migration is therefore the dimension of economic integration in Europe, which will bring the most marked changes as a consequence of the Eastern enlargement of the EU. In view of the sizeable gap in per capita income, these restrictions to the EU labour markets have resulted in a rather moderate labour migration from the CEE accession countries to the EU member states. Currently, approximately 290,000 workers from the EU accession and candidate countries are legally employed in the EU, accounting for $0.2 \%$ of the EU workforce (roughly $6 \%$ of the total non-EU workforce of 5.3 million). Broken down by sending country the total migrant stock is the following: Bulgaria 55.000, Czech Republic 35.000, Estonia 15.000, Hungary 77.000, Latvia 7.500, Lithuania 8.000, Poland 435.000 (53\%), Romania 155.000 (19\%), Slovak Republic 20.000, and Slovenia 20.000 (EC 2001c). In addition to legal workers, the number of undoc-

\footnotetext{
${ }^{1}$ In April 2001, the European Commission proposed phasing in full rights for the free movement of workers. Instituting a transition period rather than immediately recognising mobility rights is intended to "ensure the widest possible public acceptance of enlargement". During a general transition period of 5 years, Member States would continue to operate their own national measures on accepting workers from the new Member States. After no more than 2 years, the European Commission would conduct an automatic review on the basis of which the Council, acting by unanimity, and following consultation with the European Parliament, would decide whether to shorten or lift the transition period. This could lead to the full application of the aquis communautaire, perhaps combined with safeguards for exceptional circumstances. Member States that so wish, would be able to continue with national measures. After this review, "One further optional additional (sic) review per country may be held at the request of a Member State (current or new) with a view to further relaxation of controls". If any Member State experiences "serious disturbances in its labour market", it may maintain its national provisions for a further maximum period of 2 years (EC 2001a).
} 
umented workers and migrants from the accession countries has grown as a result of the combination of closed labour markets and unrestricted travel. According to the EC (2001c) estimates, currently there are 600,000 such undocumented migrants providing less expensive and flexible alternatives to local labour force.

In view of the $\mathrm{EU}$ enlargement one of the most frequently asked questions is whether a large scale East-West migration will take place once citizens of the new Member States have free access to the labour markets in the current EU Member States. This paper evaluates historically and empirically the development of the volume and structure of migration flows from the Baltic States. The present study attempts to predict how many persons might migrate from the Baltic States to Western Europe, and what will be the economic and demographic consequences of this emigration for sending and receiving countries? These two broad questions are the main subject of this paper. The first section discusses the historical evidence of the migrant flows in the EU and in the Baltic States. In the following parts, we evaluate the size and the structure of current and future migration in the Baltic States. In particular, we quantitatively evaluate the future migration pressure, based on the economic and demographic situation in the Baltic States and Western Europe. The last section concludes with political considerations dealing with free or temporary restricted access to Western Europe's labour markets.

\section{Historical Overview of Migration in Europe}

In this section we provide background for the analysis of future migration in the CEE accession countries by studying patterns of population movements in the past. We start with the post-war migration experience and historical labour movements and continue with more recent patterns of economically driven migration in Europe. Next we seek to identify migration policies, which will manage workers' movements in the European Union in the period following the EU enlargement. In light of these findings we draw conclusion for future migration trends in the CEE.

\subsection{Western Europe}

The recent history of Europe has witnessed several migration waves markedly differing with respect to sources of migration, the role of push and pull factors and consequences in the respective countries of destination. According to Zimmermann (1996), we can distinguish four migration periods in the post-war Europe: (i) war adjustment and de-colonisation (1945 - early 1960s), (ii) labour force immigration (1955-73), (iii) the period of restrained migration (1974-88), (iv) the dissolution of socialism in the East and migration to the West (since 1988). Beyond the dissolution of socialism, an increasing number of refuge seekers from regions not belonging to the former socialist world is a second major characteristic of the most recent migration period. 
Regarding the first period mentioned, some 20 million people are displaced by the war, 12 million of which were ethnic Germans. Another 2.6 million Germans moved to West Germany until this flow was stopped by the erection of the Berlin wall (OECD 1993). Smaller, but also significant flows into other countries originated from former colonies. Even though it is hard to distinguish between economic and noneconomic reasons for migration, the dominance of political push factors explaining this migration wave is obvious.

In contrast, during the second migration period economic pull factors were the driving force of the south-north migration wave starting in late fifties. According to Zimmermann (1996), about 5 million people left the Mediterranean countries to the north. When the recruitment of workers came to a halt in 1973, about 2.9 million workers from the South European countries (including Turkey) were working in the North European countries (see Table 1).

Table 1: South European Workers in North Europe, 1975-2000

\begin{tabular}{lrrrrrrrr}
\hline \hline & $\begin{array}{c}1975 \\
\text { Stock }^{\dagger}\end{array}$ & $\%^{\dagger \dagger}$ & $\begin{array}{c}1985 \\
\text { Stock }\end{array}$ & $\%$ & $\begin{array}{c}\text { 1995 } \\
\text { Stock }\end{array}$ & $\%$ & Stock & $\%$ \\
\hline Portugal & 526 & 13.9 & 526 & 11.7 & 551 & 12.4 & 471 & 11.8 \\
Spain & 506 & 4.1 & 303 & 2.2 & 218 & 1.6 & 362 & 2.9 \\
Italy & 919 & 4.3 & 675 & 3.0 & 593 & 2.7 & 565 & 2.6 \\
Greece & 240 & 6.9 & 142 & 3.8 & 145 & 3.6 & 155 & 4.4 \\
Turkey & 718 & 4.1 & 856 & 3.9 & 980 & 3.7 & 743 & 3.9 \\
Total & 2909 & 5.3 & 2502 & 4.0 & 2632 & 4.3 & 2421 & 4.3 \\
\hline \hline
\end{tabular}

${ }^{\dagger}$ Thousands of workers, ${ }^{\dagger \dagger}$ percent of labour force in the country of origin. Source: Own calculations based on OECD (1976-2001) data.

The recruitment was stopped in 1973 due to the increase of unemployment in the European host countries which, for example in Germany, jumped up from $1.1 \%$ in 1972 to $4.7 \%$ in 1974 after the first oil price shock. South-Europeans partly remigrated, and surprisingly there was no new migration wave after restrictions have been removed, when Greece and later Portugal and Spain entered the European Community in the 1980s after a transition period of several years (Broecker 2000). As a consequence, the stock of foreign labour in Northern Europe declined during the third period until the mid 1980s. However, the stock of foreign population in EU more or less stagnated. The main reason why the foreign population did not decline was that families of workers staying in the EU followed to their emigrated members, and the fertility rates of foreigners exceeded those of natives in Northern 
Europe (Burda 1995).

The fourth period migration wave, induced by the breakdown of socialism, which started in the late 1980s. According to Eurostat (2000), Germany was the main destination country for the emerging East-West migration flows, consisting of an influx of foreigners from Central and Eastern Europe, of ethnic Germans (Russlanddeutsche) and internal migration from East to West Germany. Using net migration figures, close to 2 million Russlanddeutsche and almost 3 million foreigners (1.9 million of which were asylum seekers) came to Germany in the late 1980s and the beginning of 1990s. In addition, more than 1 million people (net) moved from East to West Germany in only five years since 1988 (Burda 1995).

The increasing East-West migration cannot be explained solely by economic reasons. The opening of the Iron Curtain made migration possible, and distress from political instability in the East as well as social catastrophes in the Balkan peninsula were major driving forces of migration to the EU. However, the second important force attracting migrants was the considerable income gap between East and West (Sinn et al. 2001).

In general, the international mobility of people in the EU is rather low. On average, less than $2 \%$ of the total workforce in the EU countries comes from another Member State, although the percentage varies from country to country. This percentage has remained nearly constant over the last 15 years. According to the Eurostat (2000) labour force survey, an over-average proportion of foreign workers in the current EU countries is made up of third-country nationals, for example, in Germany where foreign workforce made up $8.6 \%$ of the total employment in 1998, only $2.8 \%$ of which came from another EU Member State.

\subsection{The Baltic States}

During the Soviet period, the Baltic States, at that time as part of the Soviet Union, attracted high numbers of immigrants from other regions within the Soviet Union, and had a strongly positive migration balance. As a result, the proportion of population of titular ethnicity (Estonians, Latvians and Lithuanians) fell drastically whilst Russian, Ukrainian, Belorussian and other ethnic groups from other Soviet regions increased substantially, particularly in Latvia and Estonia. However, the influence of migration on population structure in the Baltic States has changed significantly after regaining the independence in 1991 (see Figure 1).

In the early 1990s emigration to the countries of the former Soviet Union increased dramatically, reaching high point in Lithuania in 1992 of 21,000 persons, in Latvia and Estonia in 1993 of 28,000 and 14,000 persons respectively (see Figure 1). After more than 30 years of being positive, net migration became negative in all three Baltic countries as a result of the re-establishment of the independence and the willingness of former immigrants, the so-called "Russian speaking population", to return to their countries of origin. The main destination for the majority of emigrants was 
the Russian Federation, followed by the Ukraine and Belarus. These three nationalities alone accounts for $80 \%$ of net migration from Estonia and Latvia, and for $60 \%$ from Lithuania in 1997 (OECD 1999). After peaking in the beginning of 1990s, the migration balance remains negative in Latvia $(1,800)$ and in Estonia (600). Since 1997, Lithuania's migration balance became slightly positive again and amounts to 1,100 Persons in 1999 (see Figure 1).

Immediately after fall of the Iron Curtain, the citizens of Central and Eastern Europe made extensive use of the new acquired freedom of movement. Many saw this as a chance to travel or to emigrate at least for a short period of time to the West. Most of them travelled as tourists, some as merchants or workers. Other people came to Western Europe as asylum seekers. One of the most important reasons for the increase in the emigration was the uncertainty, about whether the changes of the political and economic systems would be successful and lasting. However, a distinct characteristic of the Baltic States is that the negative total net migration until the late 1990s was to a large extent caused by international return migration to the countries of the former Soviet Union (see above) and not to the countries of the Western Europe.

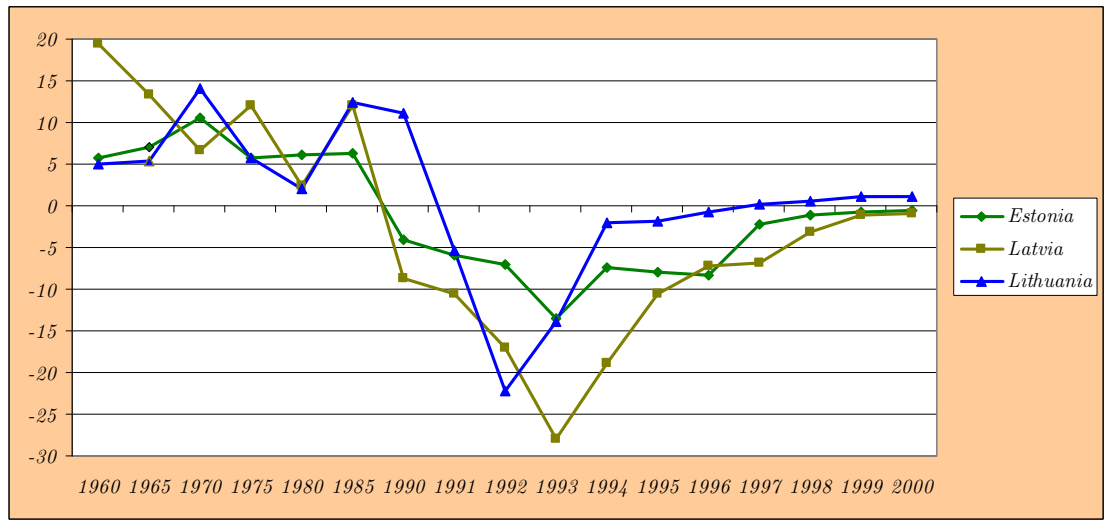

Figure 1: Net migration in the Baltic states in Thousands, 1960-2000

Source: Eurostat (2001) and European Training Foundation (1999).

Emigration flows to the West, although they are not increasing in absolute terms, are increasing compared to internal migration within the post-socialist-bloc countries as emigration to the East slowed up in the second half of the 1990s. In 1990 they accounted for only $11 \%$ of the total emigration from Estonia, $14 \%$ from Latvia and $12 \%$ from Lithuania. By 1997 the East-West migration share has increased to $22 \%$, $21 \%$ and $32 \%$ in Estonia, Latvia and Lithuania respectively. The main host countries remain unchanged over the years: Finland and Germany for Estonia; Israel, the United States and Germany for Latvia and Lithuania (Eurostat 2001, OECD 1999).

The main receiving countries of migration from the Baltic States are Germany and 
Finland. More precisely, $80 \%$ of the population who immigrated from Baltic States into the EU reside in Germany, Finland and other Scandinavian countries. The share of population from the Baltic States in total population was $0.2 \%$ in Finland, $0.02 \%$ in Germany, 0.02\% in Denmark and Sweden in 1998 (see Table 6 in the Appendix). In all other EU countries, the share of population from the Baltic States in total population is negligible. The high share of residents from the Baltic States in Germany, Finland, Sweden and Denmark relative to other EU Member States indicates that geography, culture and language (e.g. between Estonia and Finland) play a key role in migration decision.

Summarising the historical evidence of migration experience in Europe, it becomes evident that migration is only to some extent an economic phenomenon. There are no steady flows, but waves flooding over Europe, induced by different reasons, with sharply fluctuating migration policies, political disruptions and ethnic conflicts playing an eminent role beyond economic incentives. According to Layard et al. (1992) at least half of the people who have crossed the borders since the Second World War probably would have stayed, even if faced with strong international income differentials, were they not persecuted for religious, political, ethnic, gender or other reasons or were not forced to live under suppression and dictatorship. At the same time, there is a large, but difficult to quantify number of people who would move to the prosperous parts of Europe only for economic reasons, if they were not hindered by immigration restrictions.

In the context of the present study, these findings suggest that the two groups of migrants (economically and politically motivated) should be analysed separately. In this study we mainly concentrate on the economically-driven migration from the Baltic States to the Western Europe.

\section{Determinants of Migration}

Migration research identifies a series of factors that appear to influence the international migration. They can promote or restrain migration, and depending on whether they emanate from the source or host country they can be pull or push factors. They are often difficult to quantify and they interact in complex ways, rendering any precise forecasting very difficult (EC 2001c).

According to Harris and Todaro (1970), the most important driving forces of migration are differences in per capita income (income gap), the employment rate in the host countries and countries of origin, tradition and networks, ethnic and political problems, and cultural and linguistic barriers and proximity. However, due to severe data limitations, our empirical analysis cannot take into account all factors, which affect migration. Moreover, the future development of key variables like GDP growth and employment is uncertain. Therefore, in the present study we restrain to socio-economic determinants of international labour migration: income differences, the probability of finding employment in the destination country, the role of human 
capital, and demographic differences between the source and origin labour markets.

\subsection{Income Gap}

The process of transforming the previously centrally planned economies of Eastern Europe into market economies does not progress at the same rate. For example, the GDP growth rates in 2001 indicate that the economic situation in the Baltic States has improved significantly. According to Borjas (1994), the fast rapidly growing economies should lower the emigration pressure. On average, GDP in the Baltic States fell between 5\% and 7\% in 1991. Between 1993 and 1997, the Baltic States experienced substantial economic growth. In light of the recent growth performance in the Baltic States (e.g. 7\% Latvia in 2001), the migration pressure should decline with declining income gap.

According to the new growth theory, if countries have already entered the convergence path, they would rapidly bring the income level into line with the levels of the current EU Member States which must be regarded as a long-term objective for the CEE transition economies (EC 2001c).

Table 2: Income and estimated emigration from the Southern Europe, 1960-73

\begin{tabular}{lcc}
\hline \hline & GDP per capita in 1960, \% & Estimated migration rate, \% \\
\hline Portugal & 32.8 & 4.9 \\
Spain & 54.8 & 1.5 \\
Greece & 36.7 & 4.4 \\
Turkey & 28.5 & 7.6 \\
EU-8 & 100.0 & - \\
\hline \hline
\end{tabular}

Source: Own calculations based on Summers and Heston (1995).

The OECD (2000) estimates reported in Table 2, show nominal wage levels at the current exchange rates of the Baltic States slightly below one-tenth of the EU Member States. However, the relative levels vary from $7 \%$ in Lithuania to $9 \%$ in Estonia in 1997 (OECD 2000). The large difference between nominal wages in the Baltic States and EU reflects not only differences in labour productivity but also real income differences. On average, as shown in Table 2, the nominal income per capita in the Baltic States are only one seventh of the current EU average in nominal terms and less than one third in terms of purchasing parity. However, in terms of purchasing power parity real wages in the Baltic States were around one fifth of the respective levels in the EU. 
According to figures reported in Table 7 in Appendix, the level of economic development in the candidate countries relative to the EU Member States is comparable to the level of the South European accession countries relative to the European Economic Community members in 1960, when European labour immigration started. Extrapolating these figures one-to-one to the Baltic States implies that migration rates similar to countries such as Greece, Portugal or Turkey between 1960 and 1973 should be expected. More precisely, in light of figures reported in Table 1, in terms of the share of labour force of the Mediterranean countries workers working in Northern Europe in 1975, we would expect an emigration rate from CEE between $4 \%$ and $14 \%$, if we refer to the evidence from Spain and Turkey or from Portugal emigration, respectively. Extrapolating these figures one-to-one to the Baltic States would clearly point to a relatively high emigration potential. However, considering that potential economic growth in the Baltic States is higher than in the South European countries before their accession to the EU, the situation is somewhat different. Higher economic growth in the Baltic States than in the EU countries could lead to higher employment growth and much faster convergence of real income which would definitely exert a dampening effect on migration.

\subsection{Employment rate}

The supply and demand for migrant labour are generally considered to be important factors in migration decision. According to According to Borjas (1994), a high level of unemployment in the country of origin can push migration. However, a high level of unemployment in the country of destination can also have a strong effect, deterring work-seeking immigration (Stark 1991). The rate of employment in relation to the working age of the population has declined sharply in the Baltic States: starting from extremely high levels, they now remain on average at the level of $60 \%$, which is similar to the EU average (EC 2001b).

Labour market statistics for the Baltic States reveals a big difference between sixties and the current situation. South-North migration in the sixties was pulled by labour shortages in the host countries, while today, unemployment rate in the EU host countries exceeds 8-10\% (EC 2001a, EC 2001b). Adopting these figures to the present East-West migration we may conclude that this should not significantly dampen the migration incentive, because still 9 out of 10 potential migrants would get a job, if those workers newly entering the labour market were faced with the same risk of being unemployed as those workers already in the labour market. Furthermore, even if migrant workers would lose their job again, immigrants would fall back to the social security system, at least if they worked sufficiently long enough to be entitled for unemployment insurance. Taking Germany as an example, an unemployment benefit in Germany would reduce an average worker's family income to about $70 \%$ of what he would earn having a job there. However, in real terms, this is still more than twice as much as what the migrant worker would would have earned having a job at 
home in the Baltic States. On the other hand, the risk of relative deprivation may deter migration (Stark 1991). Even if an immigrant losing his job still has a higher real income than in the home country, he is still relatively poor in comparison to the host country population.

In all three Baltic States, the transition to a market economy was followed by a sharp increase in the unemployment rate, which, at least officially, did not exist in the central planning system under the Soviets. In 2001, the unemployment rates in Baltic States varied from $12.6 \%$ in Latvia to $11.3 \%$ in Lithuania in comparison to $7.6 \%$ in the average in the EU Member States (see Table 3). The two main differences between the Baltic States labour market and the European Union are long-term and youth unemployment. The long-term unemployment in the Baltic States amounts to around a half of the total unemployment. According to Table 3, in 2000 it was $47 \%$ in Estonia, $52 \%$ in Lithuania and $56 \%$ in Latvia. These figures are significantly higher than those for the EU Member States.

Table 3: Unemployment rates in the Baltics and EU

\begin{tabular}{lcccccc}
\hline \hline & 1996 & 1997 & 1998 & 1999 & 2000 & 2001 \\
\hline Estonia & 10.8 & 10.6 & 9.6 & 11.7 & 11.3 & 11.5 \\
Latvia & 22.0 & 15.7 & 14.5 & 13.7 & 13.1 & 12.6 \\
Lithuania & 19.2 & 13.6 & 12.5 & 10.2 & 10.8 & 11.3 \\
EU-15 & 10.8 & 10.6 & 9.9 & 9.1 & 8.2 & 7.6 \\
\hline Estonia & 11.8 & 11.5 & 10.5 & 13.0 & 12.9 & 12.7 \\
Latvia & 22.3 & 16.2 & 15.4 & 14.1 & 12.1 & 11.8 \\
Lithuania & 20.6 & 14.9 & 14.1 & 11.2 & 10.9 & 11.6 \\
EU-15 & 9.6 & 9.3 & 8.6 & 7.9 & 7.6 & 7.3 \\
& & \multicolumn{7}{c}{ Women } & & & \\
Estonia & 9.7 & 9.7 & 8.6 & 10.2 & 10.1 & 10.2 \\
Latvia & 21.6 & 15.2 & 13.6 & 13.2 & 13.1 & 13.3 \\
Lithuania & 17.5 & 12.1 & 10.8 & 9.2 & 10.1 & 10.3 \\
EU-15 & 12.4 & 12.3 & 11.7 & 10.9 & 10.8 & 10.5 \\
\hline \hline
\end{tabular}

Source: Eurostat (2002).

A further striking difference to the EU labour markets is gender difference in the long-term unemployment, which was insignificantly higher for men compared to women in the Baltics. While the increase in unemployment affected women proportionally more, gender differences remain smaller than in many EU countries. These findings suggest that there seems to be little potential for large-scale movements from 
the East to the West resulting from employment differentials by gender. These results are consistent with findings of Borjas (1987) and Stark (1991), which suggest that men are usually more ready to go abroad than women.

Comparing the employment rate between different age groups we note that youth unemployment (15-24 years) is rather high in the three Baltic countries and reaches around $30 \%$, which pushes especially young people abroad. A recent study of the Lithuanian Ministry of Social Affairs and Labour (2001) came to a similar conclusion that especially young unemployed persons as well as high school and college graduates consider going abroad and looking for a job in the current EU Member States, where income is significantly higher and unemployment level is somewhat lower.

Whereas unemployment in the host country reduces migration incentives, unemployment in the source country can be an additional push factor. According to figures reported in Table 3, unemployment rates in the Baltic States today are already close to the rates in the EU Member States, and will probably increase due to the structural adjustment during the integration process into the single European market (Boeri and Schaffer 1998). They may also increase after an adjustment period, because the new EU Member States have to adapt more rigid regulations in the labour market than workers from the old EU Member States.

\subsection{Human Capital}

Findings from the labour survey suggest that formal education levels of immigrants from the CEECs (inclusive the Baltic States) are significantly higher than those of other foreigners and even natives in the old EU Member States. They are therefore likely to be able to compete - like other foreigners - chiefly for blue-collar jobs in manufacturing and low-skilled jobs in service sectors. However, according to Hoenekopp (1999) and Boeri and Bruecker (2000), the ability to transfer the human capital acquired in Eastern Europe to the EU labour markets is rather poor - at least at the present stage.

As Figure 2 indicates, for example, in Germany foreigners suffer from a higher rate of unemployment than Germans. Yet, this difference can to a large extent be traced back to foreigners' lower level of qualification. Germans without a formal qualification suffer from an even higher rate of unemployment with 20\% in 1999 (Bundesanstalt für Arbeit 2001). Another reason for higher unemployment rates of foreigners compared to natives is that immigrants run a much higher risk than natives to fall into the outsider groups in the labour market, because they have less access to information and fewer possibilities to signal their abilities. Furthermore, it is also possible that the costs of losing the local network, including family ties, are valued higher by a person faced with the risk of unemployment. This implies that unemployment in the host country would diminish the willingness to move.

Despite the high unemployment rates in the EU countries, there is a demand for high-skilled technical and professional workers, especially in information technology, 


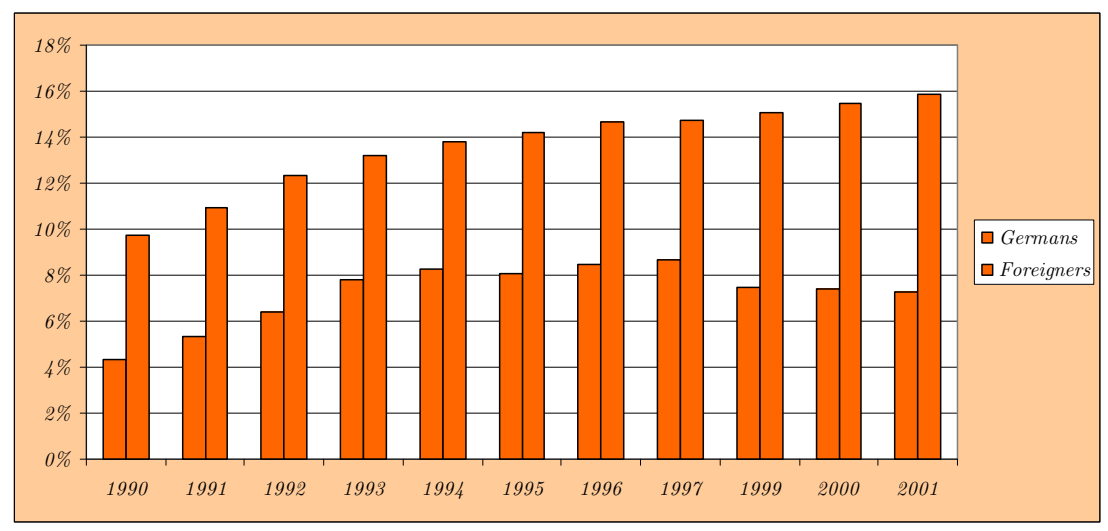

Figure 2: Unemployment rates in Germany for Germans and foreigners, 1990-2001 Source: Bundesanstalt für Arbeit (1995-2002).

as well as for low-skilled service workers. If these high-skilled workers would stay permanently in the EU, their emigration may lead to a Brain drain in the Baltic States. According to Bhagwati (1976), this might have negative consequences for their future economic development. In the case of temporary migration, however, the high-skilled workers may become acquainted with new technologies and, after return, help their source country in terms of knowledge transfer (Bauer and Zimmermann 1999, Wolburg 1999).

Summarising these findings we may conclude that emigration rates are likely to be smaller in the Baltic States than they were between Southern EU accession countries and EU Member States under the same conditions of a comparable income gap in the 1960s. Considerable level of unemployment in the current EU countries and more positive prospects of economic development in the Baltic States will play here an important role. On the other hand, extrapolating recent experiences of a nearly zero net migration from poor to rich countries in the Western Europe to the situation after Eastern expansion of the EU might lead to a considerable underestimation of potential migration rates.

\subsection{Demographic Development}

In the long run, differences in demographic developments may also be an important driving force behind migration (Zimmermann 1996). Stagnating, ageing populations tend to attract migrants, while young and large populations generate individuals that are more mobile. Therefore, it is vital to investigate demographic conditions in the Baltic and the current EU countries.

Between 1960 and the late 1980s the Baltic States had relatively high population growth due to fertility and birth rates that were relatively high by European 
standards (see Table 8 in the Appendix). Because of high fertility rates observed in the 1970s and 1980s, the three countries still have a relatively young population. After independence the demographic pattern changed dramatically. Since 1991 the total population in the Baltic States has been decreasing, with the greatest speed in urban areas. The number of inhabitants in rural areas has also started to decrease. In the first half of the 1990s it was mainly influenced by significant emigration flows as discussed in the previous chapters, though, in the second half of the 1990s more unfavourable demographic developments with much lower birth rates and higher mortality rates started. For example, over the period 1990-1997 the total population in Latvia decreased by 190,600 persons or by $7.1 \%$.

In the 1970s and 1980s, the fertility rates in the Baltic States were above two children per women much higher compared to the current EU countries. Children were born early, while in Western Europe more an more people either decided to have no children or postponed their family formation. However, the sudden introduction of the market economy and the radical changes within the political and social systems in the Baltic States led to a rapid adoption of Western fertility patterns, ultimately leading to a significant decrease in the numbers of children born in these countries. As a result, since 1989-90 a considerable decrease in fertility can be observed in all the Baltic States. Within a few years, fertility levels that used to be much higher than in the West dropped below average levels in Western Europe. The combination of a massive drop in fertility rates, the consequences of a difficult transition from socialist regimes to market economies and a less than promising health record are all responsible for the ageing of the populations of these countries. Since the demographic shift took place within a relatively short period of time, the impact on the age structure of population in these countries will be even more visible than in Western Europe. Among the main economic issues are the consequences of ageing for labour markets and national pension systems.

During the nineties, a distinct decrease in fertility leading to low birth rates and a stagnating or decreasing life expectancy leading to higher mortality were the main characteristics of the population development in the Baltic States. Especially in the second half of the 1990s these factors had a much larger impact on the demographic situation than migration. Poverty among the older generation, the cut in social benefits, especially cutbacks in basic medical treatment, led to an increase in mortality and a decreasing life expectancy. Mortality was particularly high among the male population. Furthermore, high unemployment, impoverishment and the "monetarisation" of the health system on the one hand, and persistence of unhealthy life-styles, widespread alcohol abuse and a rapidly growing number of traffic accidents on the other hand, empowered these negative trends.

Because of relatively high birth rates under the Soviet system the three Baltic States may experience an increase in the labour force as soon as their citizens born before 1990 leave the educational system. However, compared to the "baby boom" generations born in the 1970s and 1980s, addition of the labour force from the less size- 
able 1990s cohort will have rather severe implications for the Baltic labour markets. This might also have implications for the emigration potential as people belonging to smaller birth cohorts will have much better chances to find employment in their home countries. When demographic decline coincides with positive economic development, further stimulated by future EU membership, this might lead to an additional demand for labour. Therefore, it can not be ruled out that in medium to long term the Baltic States will be trying to recruit labour migrants to fill labour shortages.

These demographic trends suggest that the Baltic States are not the region from which a persistent migration to the Western Europe can be expected for simple demographic reasons. Therefore, we argue that in the medium run, transitional arrangements and transitional periods, intended to protect current EU Member States labour markets will be indeed entirely irrelevant. In the short run however, the perspective may look a bit different.

Summarising this section's findings, we may conclude that the future East-West migration will largely depend on the economic and demographic development in Eastern and Western Europe. Given that the political stability, democratic structures and human rights in the Baltic States have been developing at a rapid pace, politically motivated migration may gradually disappear. As we have discussed in the previous section, several migration theories stress that the economic conditions in the sending country in relation to the receiving country are far most important determinants for the individuals' migration decision. Therefore, the following section estimates the emigration potential in the Baltic States driven by socio-economic factors.

\section{Modelling Potential Migration}

In this section we estimate the potential cross-border migration flows in the Baltic countries as a consequence of Eastern expansion of the EU. We assume that by 2004 the Baltic States will have become EU members. The Four Freedoms of the Union will then also apply to these countries, implying that, among others, people from these countries are free to settle in the European Union wherever they want, as long as they are able to earn their livelihood. Even without that ability, they may stay in a foreign country, if they have gained entitlement for social aid, having made payments to the social security system while doing a regular job for some time.

Hence, even though certain administrative impediments will continue to exist, making international migration more difficult than intra-national migration, we assume that formal restrictions will be insignificant compared to the present situation. It is also assumed that political stability will prevail in these countries as well as the EU as a whole, and that ethnic conflicts will not give any reason to anybody to leave his home country. Of course, this might be an overly optimistic assumption but we 
want to confine this paper to economic migration incentives.

\subsection{Model Description}

This section introduces the econometric model which we use for estimating the migration potential in the Baltic States. The formal derivation of the migration model is presented in the Appendix. Choosing the dependent and independent variables as well as specifying functional form of the model, we follow the most recent empirical migration studies (e.g. Boeri and Bruecker 2000).

The starting point of our empirical specification is equation (15) in the Appendix. Given the above model specifications, another empirical complication is the problem of endogeneity. If one might assume that migration flows are relatively too small to induce reverse causality, ${ }^{2}$ there still might exist confounding factors that affect contemporaneously wages, unemployment rates and migration flows. For instance, negative demand shock, such as Russia crisis in 1998, may drive unemployment up or wages down (or both) and, at the same time, increase emigration. To (partly) get around this problem, we use instrumental variables estimation with lagged values of income, unemployment rates and migrant stocks as instruments.

As a result, we obtain a linearly estimable model of migration, were labour migration is a logarithmic function of socio-economic characteristics of source and destination countries: ${ }^{3}$

$$
M_{b e t}=\alpha_{0}+\alpha_{1} \ln \frac{Y_{e t-1}}{Y_{b t-1}}+\alpha_{2} \ln \frac{U E_{e t-1}}{U E_{b t-1}}+\alpha_{3} \ln M S_{e t-1}+\alpha_{4} \ln D_{b e}+\epsilon_{t}
$$

where $M_{b e t}$ is the gross migration rate from Baltic country $b$ to EU country $e$ in time period $t, Y$ is per capita income, $U E$ is unemployment rate, $M S$ is stock of the Baltic country b's migrants in the EU country $e$, and $D_{b e}$ is bilateral distance Baltic country $b$ and EU country $e$. Coefficients $\alpha_{1}-\alpha_{4}$ need to estimated, and $\epsilon_{t}$ is the error term. The dependent variable on the left hand side, $M_{b e t}$, the bilateral rate of migration taking place between emigration country $b$ and immigration country $e$, measures the percentage of the absolute number of migrants in the total population in the Baltic States in time period $t$.

The second and third term on the right hand side capture socio-economic differences between Baltic States and the EU. The second term on the right hand side, $\ln \frac{Y_{e t-1}}{Y_{b t-1}}$, is the logarithm of per capita income ratio in Baltic States relative to the $\mathrm{EU}$, in the previous time period, $t-1$. It is a proxy for differing wages and wealth expectations between Baltic States and the EU. The larger it is, the higher are income differences between Baltic States and the EU. Positive differences in income

\footnotetext{
${ }^{2}$ The impact of immigrants on wages in the EU destination countries might indeed be negligible because the size of Baltic countries is negligible relative to the main EU destination countries, such as Germany.

${ }^{3}$ We use $b$ as the Baltic country subscript, $e$ is the EU country subscript and $t$ is time period.
} 
should have a positive influence on emigration implying that the coefficient should be positive. The third independent variable on the right hand side, $\ln \frac{U E_{e t-1}}{U E_{b t-1}}$, is the logarithm of the ratio of unemployment rates in the EU and Baltic States in the previous period. As explained in the previous section, higher relative unemployment possibilities in the immigration country deter people from immigrating. Therefore, we expect that coefficient $\alpha_{2}$ would be negative.

The fourth and fifth term on the right hand side capture migration costs between Baltic States and the EU. The fourth right hand side variable, $\ln M S_{e t-1}$, is logarithm of the past period's stock of migrants from Baltic States living in the EU. In fact, this variable includes the stock of foreign or foreign-born population from the Baltics. It has been included in order to estimate migrants' network effects. The more immigrants live in a particular country the more likely it is that they drag further immigrants into that country. We should thus expect a positive coefficient for this variable. The fifth explanatory variable on the right hand side, $\ln D_{b e}$, is the absolute distance between the capitals of Baltic States and the EU. The distance is assumed to be a proxy for transport and transaction costs of moving as well as cultural differences between the countries. The migration costs increase with distance. Similarly, we expect that cultural differences increase with distance too. Finally, the last term is the white noise disturbance term.

The the right hand side explanatory variables included in equation (1) cover most of the theoretical approaches explaining international labour migration. For example, income differences and differences in unemployment rates between source and destination countries are both parameters, which are implicitly incorporated into the human capital approach (Sjaastad 1962). They mainly stand for the likelihood of finding a job abroad and for benefits of moving (Carrington et al. 1996). The stock of migrants already living in a destination country is an idea taken from the network migration approach (Massey et al. 1993; McCall and McCall 1987; Mincer 1978).

All independent variables in equation (1) are specified in natural logarithms. According to Boeri and Bruecker (2000), the logarithmic relationship makes sense because it is realistic to assume that the amount of push migration will not rise linearly with increase values of the independent variables. This implies that free migration follows some kind of saturation pattern. In addition to specification presented in equation (1), we also estimate an alternative (log-log) specification, where the migration rate is also a natural logarithm.

\subsection{Estimation Results}

We estimate a pooled time series and cross sectional model of bilateral migration flows from the three Baltic countries into the current EU Member States. Only those emigration flows in the Baltic States are being considered, which have arisen after fall of the Iron Curtain (1990). Table 4 reports the estimation results.

The results reported in Table 4 suggest that that all coefficients have the expected 
signs. Migration is increasing in the destination country's income relative to home country's income, and the stock of existing migrants from Baltics in the EU destination countries. As expected, migration is decreasing in the destination country's unemployment rate relative to home country's unemployment rate, and in the distance between the two countries. This positive result is a first indication that the specified migration model is consistent with data.

Table 4: Regression results for migration from Baltic countries ${ }^{\dagger}$

\begin{tabular}{lrr}
\hline \hline & Coefficient & t-statistics \\
\hline Intercept & -1.342 & -2.79 \\
$\ln Y_{e t-1} / Y_{b t-1}$ & 0.215 & 4.83 \\
$\ln U E_{e t-1} / U E_{b t-1}$ & -0.098 & -1.25 \\
$\ln M S_{e t-1}$ & 0.067 & 4.40 \\
$\ln D_{b e}$ & -0.057 & -1.81 \\
$\mathrm{~F}_{\text {-statistic }}$ & 29.30 & \\
$\mathrm{R}^{2}$ & 0.71 & \\
Adjusted $\mathrm{R}^{2}$ & 0.69 & \\
SE of regression & 0.05 & \\
Durbin-Watson & 1.73 & \\
\hline \hline
\end{tabular}

${ }^{\dagger}$ Dependent variable: gross migration rate, $M_{\text {bet }}$.

Given that all independent variables are defined in logs and the dependent variable is not, the estimation's coefficients reflect semi-elasticities. Coefficient $\alpha_{1}$ implies that a $10 \%$ increase in this period's difference of relative per capita income will ceteris paribus result in next year's increase of net migration rate into country $\mathrm{n}$ by 0.21 percentage points. $\alpha_{1}$ is significant at the $95 \%$ confidence interval. With a relatively high value of $\alpha_{1}$ and the fact that the coefficient is significant, differences in relative per capita income turn out to be the most important independent variable in our estimations. In contrast, the sign of coefficient $\alpha_{2}$ is negative which suggests that a $10 \%$ increase in the relative unemployment rate would lead to a reduction in the net migration rate by almost 0.1 percentage points. Also coefficient $\alpha_{2}$ is significant at the $95 \%$ confidence interval (see Table 4 ).

Coefficient $\alpha_{3}$ is also positive suggesting that additional $10 \%$ of foreign residents in the EU immigration country would lead to a network effect which enhance net migration in the consecutive period by 0.067 percentage points. As the other two coefficients, $\alpha_{3}$ is significant. Finally, the bilateral distance between source and destination countries, as expected, appears to have a negative effect on net migration. These results suggest that a $10 \%$ additional distance would lead to a reduced net 
migration rate of 0.057 percentage points although this coefficient turns out to be insignificant at the $95 \%$ confidence interval (see Table 4 ).

\subsection{Estimated Migration Potential from the Baltic States}

The estimated coefficient values allow us to form future expectations about the immigration potential between the Baltic States and the EU provided that we assume similarity in the ex-post and ex-ante time periods. To carry out such calculations the estimated coefficient values from Table 4 are combined with actual data for the Baltic States and the EU on per capita income, unemployment, migrant stock and distance. In doing so we assume average unemployment rates of $9 \%$ in the EU and of $12 \%$ in the Baltic States. We assume a stock of citizens of the Baltic States living in the EU of 200,000 and determine the average distance between two geographical centre points in both the EU and the Baltic States to be $2000 \mathrm{~km}$ apart. With respect to the income differentials, we calculate three different scenarios assuming values between 40-60\%. As a result, we obtain percentage rates (of the Baltic States' total population) for the estimated East-West migration rates. The projection's results are summarised in Table 5.

Table 5: Predicted migration from Baltic States into the EU

\begin{tabular}{lcrrrrrr}
\hline \hline & Total & \multicolumn{5}{c}{ Emigration by income difference } \\
& population & high $(60 \%)$ & middle $(50 \%)$ & \multicolumn{1}{c}{ low $(40 \%)$} \\
\hline Estonia & $1,400,000$ & 4,480 & $0.32^{\dagger}$ & 3,500 & 0.25 & 2,800 & 0.20 \\
Latvia & $2,400,000$ & 7,680 & 0.32 & 6,000 & 0.25 & 4,800 & 0.20 \\
Lithuania & $3,700,000$ & 11,840 & 0.32 & 9,250 & 0.25 & 7,400 & 0.20 \\
Baltic States & $7,500,000$ & 24,000 & 0.32 & 18,500 & 0.25 & 15,000 & 0.20 \\
\hline \hline
\end{tabular}

${ }^{\dagger}$ percent of source country b's population. For assumptions see Section 4.2.

Source: Own calculations based on estimations reported in Table 7.

The three columns in Table 5 differ in that they contemplate different values for income differentials varying from $40 \%$ to $60 \%$. It is obvious that with rising income differentials we obtain an increase in migration rates. Given that the average income differential between the EU and the Baltic States was approximately $65 \%$ in 2000, in the following we should concentrate on scenarios 2 and 3. The Baltic States potential emigration rates are then bounded by a lower threshold of $0.25 \%$ and an upper threshold of $0.32 \%$ of the total population in the Baltic States.

Translating these estimates into absolute numbers of migrants (by multiplying migration rates with population in the Baltic States) yields the numbers of potential 
migration from Baltic States to the EU. These results are reported in the third column of Table 5. According to results reported in Table 5, under the current economic conditions between 18.500 and 24.000 immigrants per annum coming from the Baltic States would have to be expected in the EU if free mobility of labour was allowed. When interpreting the results reported in Table 5, it is important to keep in mind that all results implicitly assume that there exists a free mobility of labour between the Baltic States and the EU simulating in such a way a hypothetical situation of the Baltic States becoming a full Member of the EU and permitting free mobility of labour.

In order to get an idea about the total migration potential, one has to consider how fast the migration incentives disappear, i.e. how fast incomes in the Baltic States catch up the present EU members in their per capita income etc. The last decade has witnessed extensive empirical research on the speed of convergence among regions or countries in several parts of the world (Aghion and Howitt 1998). The consensus in the literature is that there is a catching up tendency of poorer regions and countries, the so-called unconditional convergence. The half-life of relative income gaps may be something like 35 years, which means that - on average - the poor are expected to catch up half way with the rich within 35 years (Aghion and Howitt 1998).

The predictions for the prospective members of the EU are brighter because they will be part of a stable economic and political environment, and also because their human capital stock is regarded to exceed that of other countries on a similar income level (EC 2001b). For the Baltic States these estimates vary between 17 and 22 years (EC 2001b). However, in light of the recent growth performance in the Baltic States reported in Table 7 in Appendix, these predictions might be too optimistic. If the Baltic countries had already turned into the convergence path predicted by the new growth theory, they would have to show real growth rates of at least $5 \%$ per annum (Aghion and Howitt 1998). Over the last five years, only Estonia seems to approaching such a stable growth path, and recently also Latvia (2001) benefits from relatively high growth rates. In contrast, Lithuania is just beginning to recover after the consequences of the so-called "Russian crisis" in 1998, which had significant impact on the economies of the Baltic States. In light of these figures, we expect that income-driven incentives for migration will persist for at least next 20 years.

\section{$5 \quad$ Policy Conclusions}

This paper uses historical data to explore the likely patterns of Baltic emigration over the next decade. Based on our findings we think that there is enough evidence to predict a selective migration rather then mass migration out of Baltic countries. We would also urge that far more research should be devoted to East-West migration issues, which could become an important source for social tensions after the EU enlargement. It appears that the significant welfare differences across European countries will be at the heart of the matter and, if so, they will not be easily deflected 
without policy responses. Therefore, policy recommendation of this study is to seek out for modern and time-adequate migration laws to cope with new forms of EastWest migration, such as brain drain, and excess labour demand in source country in selected sectors.

Economically motivated migration depends to a large extent on differences in the level of prosperity between countries. As Europe will become more integrated such differences will become less marked. This fundamental reason for migration will thus decline in importance after a time. Future expectations also play a significant part in migration decision. Expecting improvements in the home countries might also lead to postpone emigration decision or to ultimately abandon the idea. Thus, the policy recommendation of this study is that bringing the income level into the line with the levels of the current EU members and achieve high level of macroeconomic stability must be regarded as a medium- to long-term objective of transition countries and their governments also from migration perspective.

In long-term and mid-term perspective free movement of labour within an enlarged European Union might be more profitable for the West European receiving countries but might be rather harmful for the Baltic sending countries. As far as a substantial proportion of the emigrants are better educated than the average workers in these countries, the loss of necessary human capital through emigration is likely to have a negative effect on productivity and economic growth in the Baltic States in a longterm perspective. Consequently, the sending countries would be harmed by a too fast and too far-reaching liberalisation of labour movements. Therefore, the policy recommendation of this current study is to postpone the right of free movement of workers within an enlarged EU until the emigration incentives are sufficiently low to avoid negative impacts on their own welfare. From the EU countries' viewpoint, the best migration policy would be to abstain from the transition arrangements, because it is the only delay of migration pressure.

As a consequence of diverging national interests (brain gain vs. brain drain), an Europe-wide policy framework is needed. Such a framework should be directed towards liberalisation of international cross-border movements but should provide an instrument to internalise externalities provoked by international migration. To avoid brain drain effects in the Baltic countries and congestion effects in the current EU countries, it might be wise to think of a migration fee that makes exit and entry more expensive.

\section{References}

[1] Aghion, P., Howitt, P., Endogenous Growth Theory, Cambridge (Mass.), MIT Press, 1998.

[2] Bauer T. and Zimmermann K., Assessment of Possible Migration Pressure and Labor Market Impact Following EU Enlargement to Central and Eastern Europe, 
Study for the UK Department for Education and Employment (Bonn, London, 1999).

[3] Bhagwati J.N., The Brain Drain and Taxation, I, II (Amsterdam, 1976).

[4] Boeri T. and Schaffer M.E., Mediating the Transition: Labour Markets in Central and Eastern Europe (London, 1998).

[5] Boeri T. and Bruecker H., The Impact of Eastern Enlargement on Employment and Labor Markets in the EU Member States, Commissioned by the Employment and Social Affairs DG of the European Commission, European Integration Consortium (Berlin and Milano, 2000).

[6] Borjas G.J., "Self-Selection and the Earnings of Immigrants", American Economic Review, 77 (1987): 531-553.

[7] Borjas G.J., "The Economics of Immigration", Journal of Economic Literature, 32 (1994): 1667-1717.

[8] Broecker J., "Migration Potential and Migration Effects after EU Enlargement", in Hedegaard, L. and Lindstroem, B. (eds.), The NEBI Yearbook 2000. North European and Baltic Sea Integration (2000): 27-47.

[9] Bundesanstalt für Arbeit, Amtliche Nachrichten der Bundesanstalt für Arbeit, Jahreszahlen (Nürnberg, 1995-2001).

[10] Burda M.C., "Migration and the Option Value of Waiting", The Economic and Social Review, 27 (1995): 1-19.

[11] Carrington W.J., Detragiache E. and Vishwanath T., "Migration with Endogenous Moving Costs", American Economic Review, 86, 4 (1996): 909-930.

[12] EC (Commission of the European Communities), Enlargement: Commission proposes Flexible Transitional Arrangements for the Free Movement of Workers, IP/01/561 (Brussels, 2001a).

[13] EC (Commission of the European Communities), Regular Report from the Commission on Progress Towards Accession by each of the Candidate Countries, Composite Paper, http://www.europa.eu.int/comm/enlargement/ (2001b).

[14] EC (Commission of the European Communities), The Free Movement of Workers in the Context of Enlargement, Information Note (Brussels, 2001c).

[15] Eurostat, Statistics (Brussels, 1999-2002).

[16] Fischer S., Sahay R. and Vegh C.A., How Far is Eastern Europe from Brussels?, in: Siebert, H. (Ed.): Quo vadis Europe? (Tübingen, 1997): 97-122. 
[17] Harris J.R. and Todaro M.P., "Migration, Unemployment and Development: a Two-sector Analysis", American Economic Review, 60 (1970): 126-142.

[18] Hoenekopp, E. and Werner, H., Eastward Enlargement of the European Union: A Wave of Immigration?, IAB Labour Market Research Topics, 40 (Nürnberg, 2000).

[19] Kancs, D. and J. Kielyte, Migration Movement in the Baltic States: Determinants and Consequences, proceedings of the UN WIDER conference,'Poverty, International Migration and Asylum', (Helsinki, 2002).

http://62.237.131.23/conference/conference-2002-3/conference\%20papers/kielyte.pdf

[20] Kiehl, M. and Werner, H., The Labour Market Situation of EU and of Third Country Nationals in the European Union, IAB-Topics, 32 (1998).

[21] Layard R., Blanchard O., Dornbusch R. and Krugman P., East - West Migration. The Alternatives (Cambridge, Mass., 1992).

[22] Martin, P.L., Trade and Migration: NAFTA and Agriculture, Institute of International Economics (Washington D.C., 1993).

[23] Martin, P.L. and Midgley, E., Immigration to the United States, Population Bulletin (June 1999).

[24] Massey D.S., Arango J., Hugo G., Kouaouci A., Pellegrino A. and Taylor J.E., "Theories of International Migration: A Review and Appraisal", Population and Development Review, 19, 3 (1993): 431-466.

[25] McCall B.P. and McCall J.J., "A Sequential Study of Migration and Job Search", Journal of Labor Economics, 5 (1987): 452-476.

[26] Mincer, J., "Family Migration Decision", Journal of Political Economy, 86 (1978): 749-773.

[27] OECD, Trends in International Migration, SOPEMI Annual Report (Paris, 19762001).

[28] Sinn H.-W., Flaig, G., Werding M., Munz S., Duell N. and Hofmann H., EU-Erweiterung und Arbeitskräftemigration, Wege zu einer schrittweisen Annäherung der Arbeitsmärkte, ifo-Institut für Wirtschaftsforschung (München, 2001).

[29] Sjaastad L.A., "The Costs and Returns of Human Migration", Journal of Political Economy, 70 (1962): 80-93.

[30] Stark O., The Migration of Labor (Oxford Cambridge, 1991). 
[31] Zimmermann K.F. "European Migration: Push and Pull", International Regional Science Review, 19 (1996): 95-128.

\section{Appendix}

Here we formally derive an empirically estimable equation of migration, which is presented in a compact form in equation (1). Sjaastad (1962) we assume that labour migration is an investment in human capital of migrants. Following Hatton (1995) we assume that the probability that individual $i(i \in 1, \ldots, n)$ from origin country $o$ migrates to destination country $d$ if the net utility differential, $\Delta U_{o d}$, is positive between the two locations:

$$
\Delta U_{o d}=U\left(y_{d}\right)-U\left(y_{o}\right)+t_{o d}
$$

where $y_{o}$ is net income at home, $y_{d}$ is net income in the destination region and $t_{o d}$ is migration cost from $o$ to $d$. As usual, we assume that the utility function in country $r$ is concave and increasing in country $r$ 's income:

$$
U\left(y_{r}\right)=\ln \left(y_{r}\right)
$$

Substituting equation (3) into equation (2) yields the following expression of net utility differential, $\Delta U_{o d}$ :

$$
\Delta U_{o d}=E \ln \left(y_{d}\right)-E \ln \left(y_{o}\right)+t_{o d}
$$

Expanding $E \ln \left(y_{d}\right)$ around $E\left(y_{d}\right)$ using the second order Taylor series expansion yields:

$$
\begin{aligned}
E \ln \left(y_{d}\right) & =\ln \left(E y_{d}\right)+\frac{E\left(y_{d}-E y_{d}\right)}{\left(E y_{d}\right)}-\frac{E\left(y_{d}-E y_{d}\right)^{2}}{2\left(E y_{d}\right)^{2}} \\
& =\ln \left(E y_{d}\right)-\frac{\operatorname{Var}\left(y_{d}\right)}{2\left(E y_{d}\right)^{2}}
\end{aligned}
$$

Following Todaro (1969) we assume that workers' only source of income is employment, which is given by $E y_{d}=w_{d} e_{d}$, where $w_{d}$ is real wage in country $d$ and $e_{d}$ is the probability of employment. The probability of employment, which is the only source of uncertainty in $y$ in region $d$, is an increasing function of employment rate (or, equivalently, 1 minus the unemployment rate). The employment probability in country $d$ can then be described by following a binominal distribution with expected value $e$ and variance $e(1-e)$. This allows us to rewrite equation (5) as follows: 


$$
\begin{aligned}
E \ln \left(y_{d}\right) & =\ln \left(E y_{d}\right)-\frac{1}{2} \frac{w_{d}^{2} e_{d}\left(1-e_{d}\right)}{w_{d}^{2} e_{d}^{2}} \\
& =\ln \left(E y_{d}\right)-\frac{1}{2} \frac{\left(1-e_{d}\right)}{e_{d}} \\
& \approx \ln \left(E y_{d}\right)+\frac{1}{2} \ln \left(e_{d}\right)
\end{aligned}
$$

Equation (6) allows us to express the expected income, $E \ln \left(y_{d}\right)$, as a function of wage rate, $w_{d}$, and employment rate, $e_{d}$, in country $d$ :

$$
\begin{aligned}
E \ln \left(y_{d}\right) & =\ln \left(w_{d}\right)+\ln \left(e_{d}\right)+\frac{1}{2} \ln \left(e_{d}\right) \\
& =\ln \left(w_{d}\right)+\frac{3}{2} \ln \left(e_{d}\right)
\end{aligned}
$$

Uncertainty about employment abroad represented by the variance term leads to a greater weight on the employment rate, $e_{d}$, than wage rate, $w_{d}$. On the other hand, staying at home is typically associated with less uncertainty about employment. Hence, the expected utility which workers draw from income at home can be written as:

$$
E \ln \left(y_{o}\right)=\ln \left(w_{o}\right)+\frac{3}{2} \gamma \ln \left(e_{o}\right)
$$

where parameter $\gamma$ captures differences in employment uncertainty at home and abroad $(\gamma<1)$. Substituting equations (7) and (8) into equation (2) yields the expression for differences in the maximum attainable utility between origin and destination regions:

$$
\Delta U_{o d}=\ln \left(w_{d}\right)+\frac{3}{2} \ln \left(e_{d}\right)-\ln \left(w_{o}\right)-\frac{3}{2} \gamma \ln \left(e_{o}\right)+t_{o d}
$$

According to Harris and Todaro (1970), the decision to migrate depends not only on the present utility but also on future expectations. In order to account for expected future gains from migration, we denote the expectation at time $t$ of the net present value (NPV) of the difference in expected utility streams from $(t+1)$ onwards by $\Delta U_{i t+1}$. Then the NPV of moving in period $t$ is $\Delta U_{i t}+\Delta U_{i t+1}$. Thus, the probability that individual $i$ will migrate in period $t$ is given by:

$$
\operatorname{Pr}\left(m_{i t}=1\right)=\operatorname{Pr}\left(\Delta U_{i t}+\Delta U_{i t+1}\right)>0 \cap \Delta U_{i t}>0
$$

Aggregating the migration probability over all individuals, the aggregate emigration rate, $M_{t}$, can be written as: 


$$
M_{t}=\alpha\left(\delta \Delta U_{i t}+\Delta U_{i t+1}\right)
$$

where the slope parameter $\alpha$ captures the impact of differences in utility between the two periods on migration rate, $M_{t}$, and $\delta$ reflects the larger weight of current conditions implying that the potential migrants might postpone the migration decision if $\Delta U_{i t}<0$. This condition implies that, even though the NPV of migrating in period $t$ might be positive, it might be even higher in period $t+1$. In this case the potential migrants have an option value of waiting.

For the sake of simplicity, in the present study we assume that the probability that individual $i$ will migrate at time $t$ depends only on $\Delta U_{i t}$. This assumption allows us to rewrite equation (10) as follows:

$$
\operatorname{Pr}\left(m_{i t}=1\right)=\operatorname{Pr}\left(\Delta U_{i t}\right)>0
$$

The aggregate migration rate $M_{t}$ can then be rewritten as follows:

$$
M_{t}=\alpha \Delta U_{i t}
$$

Following Boeri and Bruecker (2000), we assume that $\bar{t}_{o d}$, the mean of migration cost, $t_{o d}$, over all individuals, is determined by the stock of previous emigrants and by the distance between source country $o$ and destination country $d$. The stock of previous emigrants captures network effects and the bilateral distance is used as a proxy for increasing migration costs as more distant is destination country from source country.

$$
\bar{t}_{o d}=\theta_{0}+\theta_{1} \ln S_{d}+\theta_{3} \ln D_{o d}
$$

where $S_{d}$ is the stock of migrants from country, $o$, in country, $d$, and $D_{o d}$ is bilateral distance between source country $o$ and destination country $d$. Combining equations (9), (13) and (14) we obtain the following expression for gross migration rate from origin country $o$ to destination country $d$ :

$$
M_{o d t}=\alpha \ln \frac{w_{d t}}{w_{o t}}+\alpha \ln \frac{3}{2} \frac{e_{d t}}{e_{o t}}+\alpha \theta_{1} \ln M S_{d t}+\alpha \theta_{3} \ln D_{o d}+\alpha \theta_{0}
$$

According to equation (15), the migration rate, $M_{\text {odt }}$, from origin country $o$ to destination country $d$ is a function of relative wages and relative employment rates in the origin and destination countries, the existing stock of migrants from country $o$ in country $d$, and the bilateral distance between the two countries. 


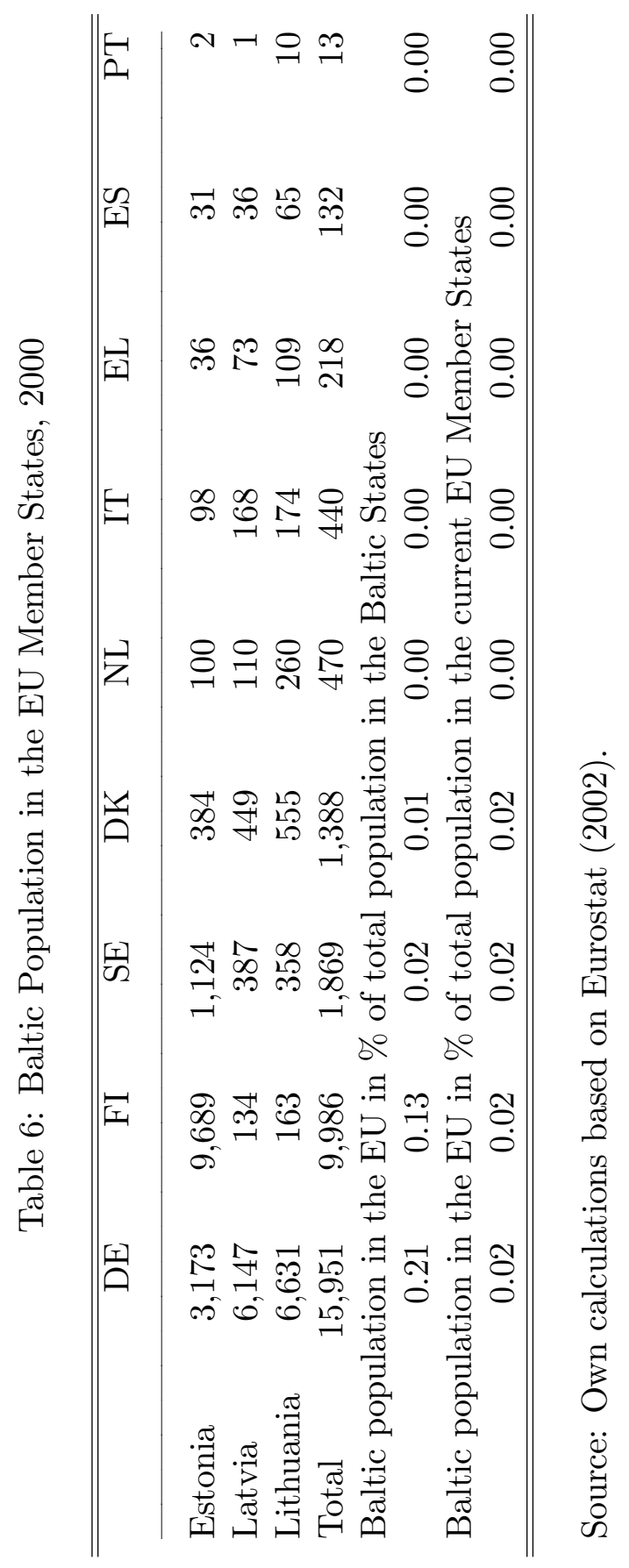




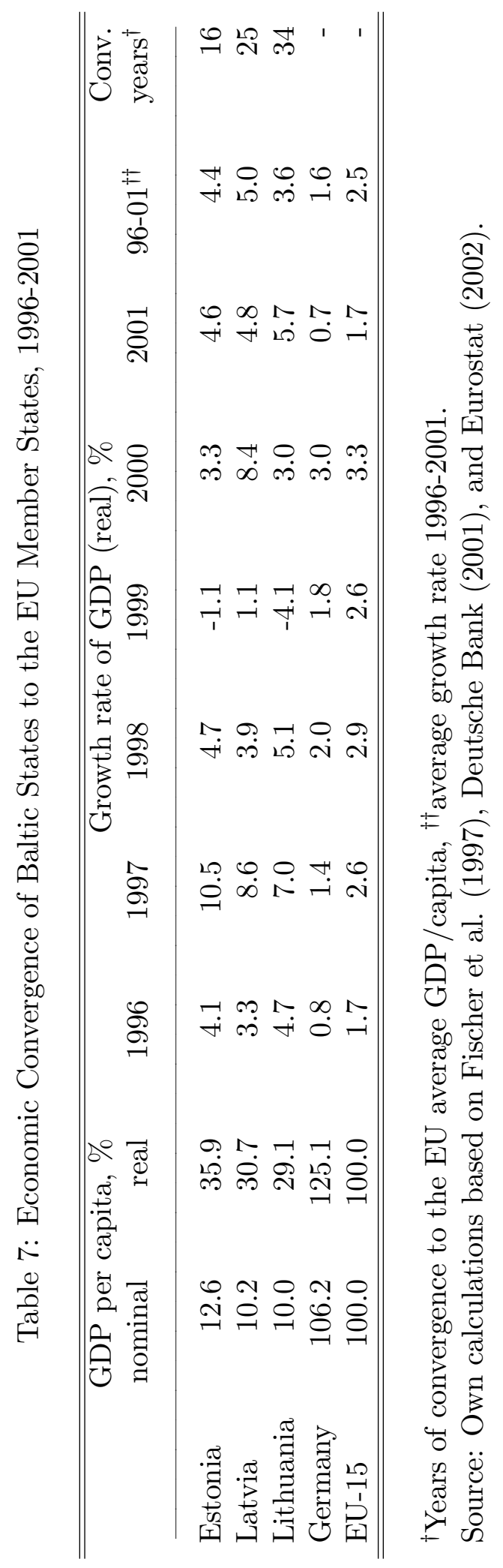




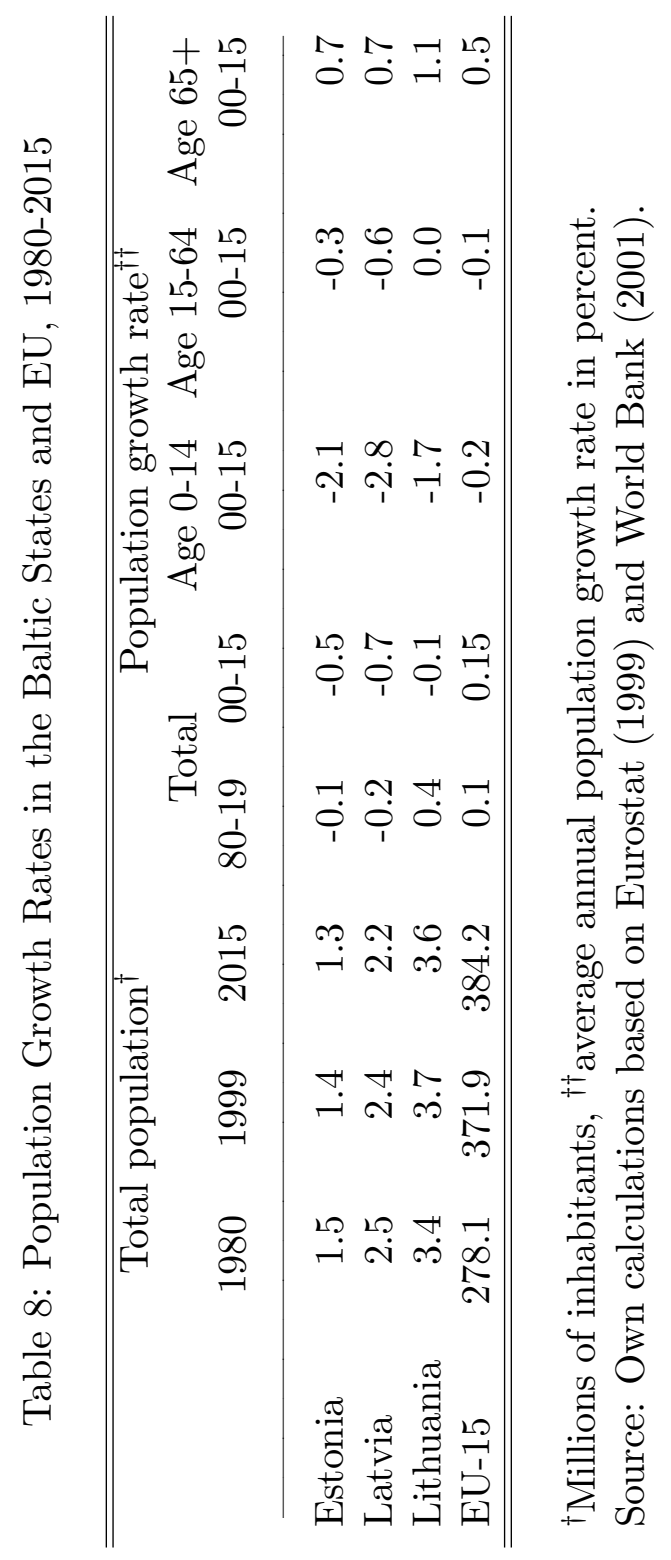

